\title{
Proces USA vs. Karl Brandt et al. a jeho význam pro rozvoj lékařské etiky v oblasti lékařských experimentů v prvních dvou dekádách po konci II. světové války
}

\author{
Jan Beránek
}

Právnická fakulta Univerzity Karlovy

Kontaktni email: honza.beranek@volny.cz

The USA vs. Karl Brandt et al. Trial and its Importance for the Development of Medical Ethics in Medical Experiments in First Two Decades Following the End of the WW2

\begin{abstract}
:
The paper deals with the topic of the first Subsequent Nuremberg Military Trial USA vs. Karl Brandt et al. also known as "Doctors trial" or "Medical trial" and its importance for the development of medical ethics in the modern era. The paper discusses circumstances, which led to the trial, the philosophy behind it and the actual proceedings of the tribunal. The author tries to analyze the defenses of the defendants as well as the main arguments of the prosecutors. The aim of the second part of the article is to analyze the impact of the so-called Nuremberg Code, the set of medical ethical rules, which were defined in the judgment of the Tribunal, on the development of the modern medicine ethical principles. In the final part of the paper, the author tries to sum up positives and negatives of the proceedings and its subsequent impact on the medical profession.
\end{abstract}

Keywords: Medical trial; Nazi physicians; Subsequent Nuremberg trials; Nuremberg code

Klíčová slova: Medicínský proces; nacističtí lékaři; Následné norimberské procesy; Norimberský kodex

DOI: $10.14712 / 2464689 X .2021 .7$ 
Hrůzy II. světové války a dřive nepředstavitelné zločiny nacismu představovaly významný zlom v dějinách dvacátého století. Po skončení bojů bylo zřejmé, že je třeba reagovat na válečné události a zároveň reformovat některé oblasti lidské činnosti, pro př́pad, že by v budoucnosti opět vyvstala státní moc, která by legalizovala ty nejzákladnější zločiny proti přirozenému právu, tak jako to udělal nacistický režim.

Období po konci II. světové války se neslo ve znamení rozvoje spolupráce států na mezinárodní úrovni a mezinárodního práva (především pak mezinárodního práva trestního). V reakci na nacistické zločiny však docházelo i v jiných oborech k rozvoji určitých „bezpečnostních opatření“, která měla sloužit jako jakási mezinárodním právem garantovaná a vymahatelná minima profesní etiky v daných oborech. Jedním z nejvýznamnějších takto reformovaných oborů bylo lékařství.

Cílem tohoto článku je v základních rysech nastínit hlavní proces s představiteli nacistické medicíny a následný poválečný vývoj lékařské etiky v oblasti lékařských experimentů, který byl ovlivněn právě těmito procesy.

\section{Proces USA vs. Karl Brandt et al.}

Proces USA vs. Karl Brandt et al. známý též jako „Medicínský proces“ či „Proces s nacistickými lékaři“ byl prvním z dvanácti takzvaných „Následných norimberských procesư“, tedy procesů s významnými vojenskými veliteli a představiteli různých odvětví spjatých s nacistickým režimem ve výlučné jurisdikci Spojených států.

Podněty k vytvoření samostatného procesu s představiteli nacistické medicíny vyplynuly již v průběhu hlavního Norimberského procesu, tedy procesu USA et al. vs. Hermann Wilhelm Göring et al. Během přípravy tohoto procesu, konkrétně během přípravy obžaloby Hermanna Göringa, vyšlo najevo, že někteří z lékařu Luftwaffe prováděli na vězněných osobách v koncentračních táborech zvlášt' trýznivé a vražedné pokusy s nízkým tlakem, mrazem a mořskou vodou, jejichž výsledky měly sloužit pro potřeby letců Luftwaffe. ${ }^{1}$ Po těchto zjištěních začaly prokuratury všech vítězných mocností shromažd'ovat důkazy o nacistických experimentech v celém rozsahu. Některé z informací získaných při vyšetřování byly použity během hlavního líčení mezinárodního a prvního Norimberského procesu jako důkazy proti obžalovanému Göringovi a obžalované organizaci SS. Za zmínku stojí, že byly citovány zprávy o zločinné činnosti čtrnácti lékařů, kteří byli později souzeni $\mathrm{v}$ rámci procesu USA vs. Karl Brandt et al. ${ }^{2}$

Důvodem, proč byl proces s nacistickými lékaři zahájen jako první z tzv. Následných norimberských procesů, bylo dle tvrzení tehdejšího vrchního amerického vojenského prokurátora, generála Telforda Taylora, to, že o zločinných pokusech nacistických zdravotnických pracovníků bylo nashromážděno velké množství přesvědčivých důkazů, a Taylor se tedy domníval, že prŕíprava tohoto procesu bude nejjednodušší a jeho průběh bezproblémový. Někteří starší autoři poukazovali na to, že rozhodnutí zahájit „Následné norimberské procesy“ medicínským procesem bylo ovlivněno tehdejší politickou situací v USA, jelikož představitelé Spojených států nebyli přesvědčeni o tom, že by měli být v rámci procesů souzeni i němečtí průmyslníci, a odmítali, aby byl program procesů

1 FREYHOFER, H. H. Nuremberg Medical Trial: The Holocaust and the Origin of Nuremberg Medical Code. New York: Peter Lang Publishing, 2004, s. 49.

2 WEINDLING, P. J. Nazi Medicine and the Nuremberg Trials: From Medical Warcrimes to Informed Consent. New York: Palgrave Macmillan, 2004, s. 97-98. 
zahájen právě procesem s některým z průmyslníků. Tuto teorii však většina současných autorů odmítá jako nepřesvědčivou a upozorňuje na to, že nic nenasvědčuje tomu, že by Taylor plánoval procesy zahájit jiným př́padem a že by své rozhodnutí změnil kvưli politickému tlaku. ${ }^{3}$

Proces byl zahájen 5. prosince 1946, na lavici obžalovaných usedlo celkem 23 obžalovaných, z toho dvacet osob s lékařským vzděláním a tři důstojníci SS bez lékařského vzdělání. Mezi obžalovanými byli kromě lékařủ působících v koncentračních táborech také např́íklad Hitlerův osobní lékař Karl Brandt, který spolu s dalšími nacisty, spoluobžalovaným Viktorem Brackem a v době zahájení procesu již zesnulým Philippem Bouhlerem, stál v čele nechvalně proslulého nacistického projektu eutanazií „Akce T4“, či Wolfram Sievers, vedoucí Ústavu pro vojenský vědecký výzkum, který byl součástí Himmlerovy pseudovědecké organizace Ahnenerbe. Mezi obžalovanými byl rovněž Karl Gebhardt, lékař, který stál v čele lékařského týmu, který pečoval o zraněného zastupujícího ř́išského protektora Reinharda Heydricha, a který odmítl doporučení dalšího z Hitlerových osobních lékařů, Theodora Morella, aby Heydrichovi byly nasazeny antibiotické sulfanilamidy, v důsledku čehož Heydrich zemřel na sepsi organismu. Tato událost značně pošramotila Gebhardtovu pověst mezi nacisty, a proto na Himmlerovo doporučení přijal místo lékaře $\mathrm{v}$ koncentračním táboře Ravensbruck a později i v koncentračním táboře Osvětim, kde prováděl na vězněných osobách zvrácené pokusy, jejichž cílem bylo prokázat zbytečnost a neefektivnost využívání sulfanilamidů v léčbě. Tyto pokusy pak tvořily základ jeho obžaloby v následném procesu. ${ }^{4}$ Naproti tomu někteří z nejvíce nechvalně proslulých nacistických lékařů mezi obžalovanými chyběli. Josefu Mengelemu se podařilo uprchnout z Německa, proti Aribertu Heimovi neměla prokuratura konkrétní důkazy, a proto ho neurčila jako jednoho z obžalovaných v procesu (Heim byl následně za nejasných okolností propuštěn $\mathrm{z}$ amerického vězeňského tábora $\mathrm{v}$ rámci částečné vánoční amnestie v roce 1947 a do roku 1962, kdy z Německa uprchl v obavě z hrozícího procesu, působil jako soukromý gynekolog), 5 Sigismund Rascher byl popraven v Dachau členy SS pár dní před osvobozením tábora americkými jednotkami, pravděpodobně na osobní rozkaz Heinricha Himmlera. Rascherův případ byl poměrně zajímavý. Rascher byl v roce 1944 spolu se svou ženou zatčen, poté co bylo zjištěno, že jeho tvrzení o tom, že díky jeho výzkumu plodnosti jeho žena v krátkém období třikrát otěhotněla a porodila zdravé dítě po 48. roku jejího života, je založeno na podvodu, a manželská dvojice těhotenství pouze předstírala a děti unášela či kupovala, na což se přišlo, když byla Rascherová chycena při pokusu unést dítě z mnichovské porodnice. Rascher byl na prŕíkaz Himmlera, který celou situaci bral jako osobní potupu, jelikož Rascherovy vědecké výzkumy veřejně vychvaloval a použil fotografie jednoho údajného Rascherova dítěte jako propagandistický materiál, zatčen pro únos, zpronevěru, podezření z vraždy a podvod a spolu s manželkou vězněn

3 HELLER, K. J. The Nuremberg Military Tribunals and the Origins of International Criminal Law. New York: Oxford University Press, 2011, s. 51-52.

4 BARTROP, P. R. - GRIMM, E. E. Perpetrating the Holocaust: Leaders, Enablers, and Collaborators. Santa Barbara: ABC-CLIO, 2019, s. 99-100.

5 AUTOR NEZNÁMÝ. Nazi war crimes: the hunt for Doctor Death. The Independent, 2008. [online]. Dostupné na: https://www.independent.co.uk/news/world/politics/nazi-war-crimes-the-hunt-for-doctor -death-863921.html. [cit. 10. 02. 2019]. 
v koncentračním táboře Buchenwald a následně v koncentračním táboře Dachau, kde byl i popraven. ${ }^{6}$

Obžaloba obsahovala celkem čtyři žalobní body - válečné zločiny, zločiny proti lidskosti, členství v zločinecké organizaci (konkrétně v organizaci SS) a účast na společném plánu a spiknutí za účelem spáchání válečných zločinů nebo zločinů proti lidskosti. V žalobních bodech zabývajících se válečnými zločiny a zločiny proti lidskosti byly popsány jednotlivé experimenty a lékařské zločiny, z nichž byli obžalovaní viněni. Kromě již zmíněných experimentů s nízkým tlakem, mrazem a mořskou vodou, šlo o experimenty, během kterých byli vězni nakaženi malárií, infekční žloutenkou, skvrnitým tyfem, byli vystaveni jedu, yperitu, sulfanilamidům a zápalným bombám, museli se podrobit nucené sterilizaci a pokusům spojeným s nedobrovolnou transplantací kostí a pozorováním hojivosti poškozených kostí a narušené svalové a nervové tkáně. ${ }^{7}$ Kromě výše zmíněných zločinných pokusů byli někteří z obžalovaných viněni i ze zločinů neexperimentální povahy, konkrétně šlo o zločiny spojené s realizací nacistického programu eutanazie, jehož skutečným cílem bylo vyvraždění všech duševně nemocných, fyzicky postižených, přestárlých, nevyléčitelně nemocných a dalších osob na území Ríše a na nacisty ovládaných územích, $\mathrm{s}$ vraždami deseti tisíců polských zajatců viněných nacisty z toho, že jsou nakaženi tuberkulózou, a s vraždami sto dvanácti osob židovského původu ve snaze vytvořit na univerzitě ve Štrasburku sbírku koster, které měly potvrzovat zvrhlou nacistickou teorii o podřadnosti židovské rasy. ${ }^{8}$

Již v úvodní řeči dal vrchní prokurátor Taylor jasně najevo, že proces nemá sloužit pouze k odsouzení a potrestání obžalovaných, ale že jeho hlavní hodnota má spočívat v jasném pojmenování a prokázání zvěrstev, které nacističtí lékaři prováděli:

„....Jsou zde mnohem významnější povinnosti, které musíme dnes splnit. Jsou to povinnosti vůči lidem a rasám, na které tyto zločiny dopadly. Pouhé potrestání obžalovaných, nebo i těch tisíců ostatních, kteři jsou stejně vinni, nemůže nikdy vyléčit zranění, které nacisté způsobili těmto nešt’astným lidem. Pro ně je mnohem podstatnější, aby tyto stěží uvěřitelné události byly nezpochybnitelně a veřejně prokázány tak, aby v budoucnu nikdo nemohl pochybovat o tom, že tyto události byly skutečností a nikoliv báchorkou... I přes výše řečené zde máme i další povinnosti. Osoby na lavici obžalovaných jsou obviněny z vraždy, avšak toto nejsou žádné běžné vraždy. Nemůžeme se uspokojit s tím, že prokážeme, že výše uvedené činy byly spáchány, a že je spáchaly konkrétní osoby. Zabíjet, mrzačit a mučit je trestné dle všech moderních právních řádů. Tito obžalovaní nezabíjeli v afektu, nebo pro osobní obohacení. Někteří z nich mohou být sadisté, kteří zabíjeli a mučili ze sportu, ale ne každý z nich je vyšinutý. Nejsou to hlupáci. Většina z nich jsou zkušení lékaři, někteří z nich dokonce renomovaní vědci. A přesto tito obžalovaní, kteří všichni plně chápali povahu svých činů a z nichž většina měla schopnosti vytvořit si jasný morální a odborný názor, jsou odpovědní za masové vraždy a nevýslovně kruté mučení. Je naším hlubokým závazkem vůči všem lidem na světě, ukázat proč a jak se tyto zločiny staly. Je

\footnotetext{
6 BERGER, R. L. Human Nazi Science - The Dachau Hypothermia Experiments. The New England Journal of Medicine. 1990, roč. 322, č. 20, s. 1439. Dostupné také na: https://www.nejm.org/doi/pdf/10.1056 /NEJM199005173222006.

7 Obžaloba ve věci USA vs. Karl Brandt et al. z 25. ř́jina 1946. [online]. Dostupné na: http://www.loc.gov $/ \mathrm{rr} /$ frd/Military_Law/pdf/NT_war-criminals_Vol-I.pdf. [cit. 17. 02. 2019].

$8 \quad$ Obžaloba ve věci USA vs. Karl Brandt et al. z 25. řijna 1946, op. cit.
} 
nutné osvětlit myšlenky a motivace, které vedly tyto obžalované, aby se k jiným lidem chovali hưře než ke zvířatům. Tyto zvrácené myšlenky a pokřivené ideje, které vyvolaly tato zvěrstva, nejsou mrtvé. Není možné je zabít vojenskou silou. Nesmí se stát rakovinou v prsu lidskosti. Musí být vyříznuty a odhaleny..."9

Proces byl veden, stejně jako ostatní procesy v rámci tzv. „Následných norimberských procesư“, na základě Zákona Spojenecké kontrolní rady č. 10, o potrestání osob vinných spácháním válečných zločinů, zločinů proti míru a zločinů proti lidskosti, který byl přijat 20. prosince 1945, a který vymezoval základní skutkové podstaty (zločiny proti míru, zločiny proti lidskosti, válečné zločiny a členství ve zločinecké organizaci), tresty za ně, práva a povinnosti jednotlivých představitelů vítězných mocností v jednotlivých okupačních zónách ve vztahu k pronásledování a trestání válečných zločinců, a upravoval postup pro vydávání válečných zločinců do různých států a okupačních zón, kde byli stíháni. ${ }^{10}$

Právě vymezení jednotlivých skutkových podstav v Zákonu Spojenecké kontrolní rady č. 10 představovalo jeden ze sporných aspektů procesu. Obhájci některých obžalovaných namítali, že účast na společném plánu a spiknutí za účelem spáchání válečných zločinů nebo zločinů proti lidskosti, která byla v obžalobě prvním žalobním bodem, není skutkovou podstatou, kterou by Zákon Spojenecké kontrolní rady č. 10 znal, a účast na společném plánu a spiknutí jsou v zákoně uvedeny pouze jako jedno z jednání, která naplňují skutkovou podstatu zločinů proti míru, a proto není možné obžalované shledat v tomto žalobním bodě vinnými, jelikož by to znamenalo popření zásady nullum crimen sine lege. Tribunál se k této otázce vyjádřil dne 14. července 1947, kdy konstatoval, že Zákon Spojenecké kontrolní rady č. 10, ani Charta Mezinárodního vojenského tribunálu, na jejímž základě bylo rozhodováno v hlavním norimberském procesu USA et al. vs. Hermann Wilhelm Göring et al., skutečně neobsahují spiknutí jako samostatnou skutkovou podstatu, a tudíž Tribunál nemůže ke spiknutí jako samostatnému bodu obžaloby přihlížet, avšak zároveň konkrétní jednání, která dle prokurátorů zakládají odpovědnost za účast na společném plánu, obsažené v tomto žalobním bodě, spolu s jednáními zakládajícími odpovědnost za spiknutí naplňují skutkové podstaty válečných zločinů a zločinů proti lidskosti, a proto zároveň ani první žalobní bod nelze zcela vyškrtnout a pominout. ${ }^{11}$ Tribunál zároveň zdůraznil, že toto rozhodnutí nemá sloužit k oslabování efektivnosti Zákona Spojenecké kontrolní rady č. 10, nebo odpírat obžalobě a obhajobě možnost předložit důkazy o válečných zločinech a zločinech proti lidskosti. ${ }^{12}$

Obhajoba se snažila jednání obžalovaných omlouvat v několika rovinách. V první řadě poukazovala na to, že jednání obžalovaných bylo ovlivněno mimořádným stavem, který v Německu panoval, a válečnou nutností. Právě tato mimořádná situace dle obhajoby

$9 \quad$ Úvodní řeč vrchního prokurátora Telforda Taylora ve věci USA vs. Karl Brandt et al. z 9. prosince 1946. [online]. Dostupné na: http://www.loc.gov/rr/frd/Military_Law/pdf/NT_war-criminals_Vol-I.pdf. [cit. 17. 02. 2019].

10 Zákon Spojenecké kontrolní rady č. 10, o potrestání osob vinných spácháním válečných zločinů, zločinů proti míru a zločinů proti lidskosti, přijatý 20. prosince 1945. [online]. Dostupné na: http://avalon.law.yale .edu/imt/imt10.asp. [cit. 23. 02. 2019].

11 Rozhodnutí tribunálu ohledně prvního žalobního bodu ve věci USA vs. Karl Brandt et al. z 14. července 1947. [online]. Dostupné na: http://www.loc.gov/rr/frd/Military_Law/pdf/NT_war-criminals_Vol-II.pdf. [cit. 23. 02. 2019].

12 Rozhodnutí tribunálu ohledně prvního žalobního bodu ve věci USA vs. Karl Brandt et al. z 14. července 1947, op. cit. 
dekriminalizovala jednání, v tomto př́ípadě pokusy, které měly dle obhajoby vést ke zlepšení podmínek vojáků bojujících na frontě, které by byly v dobách míru trestné. Tento druh obhajoby např́klad zvolila obhajoba Karla Gebhardta, která tvrdila, že jeho pokusy se sulfanilamidy byly nezbytné ke zjištění jejich efektivnosti a správného dávkování pro zraněné vojáky a k tomuto účelu nebylo možné použít údaje získané v době míru, jelikož specifická zranění vojáků nešla připodobnit k případům, ve kterých byly sulfanilamidy aplikovány v mírovém období. ${ }^{13}$

Dalším častým argumentem obhájců byla skutečnost, že pokusy sloužily jako alternativa $\mathrm{k}$ trestům, které byly obětem $\mathrm{v}$ koncentračních táborech uloženy. Tento argument se jeví vzhledem k vražedné a zvrácené povaze pokusů jako obzvláště absurdní, o čemž svědčí i reakce obžaloby:

„Další z poměrně běžných obhajob použitých obžalovanými je to, že pokusné osoby byly zločinci odsouzenými k smrti, kterým, pokud experiment přežili, byl trest zmírněn na doživotí v koncentračním táboře. Pro toho, kdo má byt' jen minimální povědomí o životních podmínkách v koncentračních táborech a o vyhlídkách průměrné osoby vězněné $\mathrm{v}$ těchto táborech, se tato obhajoba jeví jako morbidní vtip. Koncentrační tábory nebyly běžným vězeňským zařízením, které známe z jiných států, pro osoby odsouzené soudem za trestný čin. Základním účelem koncentračních táborů byl útlak a persekuce osob, které byly nacisty označené jako nežádoucí na základě rasy, politického názoru nebo náboženského smýšlení... A i kdybychom na okamžik připustili, že tato obhajoba má za určitých podmínek charakter polehčující okolnosti, rozhodně to neplatí v tomto prrípadě... Pokud byla obět' pokusů původně odsouzena pouze na základě toho, že je Žid, Polák nebo Rus, nebo že měla např́íklad sexuální styk se Židem, nemění trestnost tohoto pokusu pouhé konstatování, že tato obět' byla tak jako tak odsouzena k tomu zemřít. Experimentování na takové osobě je stvrzení původního zločinu spočívajícího v nezákonném uvěznění a zároveň spáchání dalšího zločinu - mučení a vraždy... Navíc nezpochybnitelné důkazy prokazují, že přežití experimentu nebylo zárukou upuštění od popravy. Nejméně šest osob bylo popraveno po tom, co přežilo experimenty. Nešlo o případy „experimenty nebo poprava“, ale o př́pady ,experimenty a poprava“. ${ }^{14}$

Posledním, velmi rozšiřreným druhem obhajoby, bylo konstatování, že experimenty obžalovaných přispěly k celkovému rozvoji lékařské vědy a byly jedinou možností, jak tohoto pokroku dosáhnout. Tento argument s nutností pokusů pro další rozvoj lékařských poznatků používala např́iklad obhajoba Hermanna Becker-Freysenga ve snaze omluvit jeho zvrácené pokusy s mořskou vodou tím, že se jednalo o snahu vyřešit v té době velice rozšířený problém ztroskotaných letců bez př́stupu k pitné vodě. ${ }^{15}$

Rozsudek ve věci USA vs. Karl Brandt et al. byl vyhlášen dne 19. srpna 1947. Sedm obžalovaných bylo odsouzeno k trestu smrti, pět bylo odsouzeno k trestu odnětí svobody

13 Závěrečná obhajoba Karla Gebhardta ve věci USA vs. Karl Brandt et al. z 15. července 1947. [online]. Dostupné na: http://www.loc.gov/rr/frd/Military_Law/pdf/NT_war-criminals_Vol-II.pdf. [cit. 23. 02. 2019].

14 Závěrečná řeč obžaloby ve věci USA vs. Karl Brandt et al. ze 14. července 1947. [online]. Dostupné na: http://www.loc.gov/rr/frd/Military_Law/pdf/NT_war-criminals_Vol-II.pdf. [cit. 23. 02. 2019].

15 Závěrečná obhajoba Hermanna Becker-Freysenga ve věci USA vs. Karl Brandt et al. z 18. července 1947. [online]. Dostupné na: http://www.loc.gov/rr/frd/Military_Law/pdf/NT_war-criminals_Vol-II.pdf. [cit. 23.02. 2019]. 
na doživotí, čtyři byli odsouzeni k trestu odnětí svobody v rozmezí deseti až dvaceti let a sedm osob bylo zproštěno obžaloby. ${ }^{16} \mathrm{~V}$ souladu s výše zmíněným rozhodnutím nebyl nikdo z obžalovaných shledán vinným v prvním bodě obžaloby. ${ }^{17}$ Ze všeho výše uvedeného vyplývá, že, navzdory tvrzeným obhajobám, nacističtí lékaři zcela, a do té doby nevídaně, rezignovali na nepsaná etická pravidla své profese takovým způsobem, který před událostmi II. světové války nebyl představitelný. Tyto události vedly k obnovení debaty o tom, že je třeba základní etická pravidla lékařského výzkumu kodifikovat a prosadit jejich univerzální závaznost. Tato snaha byla jasně patrná i v rozsudku Tribunálu, ve kterém byla mimo jiné uvedena základní etická pravidla pro lékařský výzkum:

„1. Dobrovolný souhlas lidského subjektu je zcela nezbytný. To znamená, že jakákoliv zúčastněná osoba by měla mít právní způsobilost udělit souhlas. Jinak řečeno měla by projevit svobodnou vůli bez ovlivnění silou, podvodem, oklamáním, tísní, nátlakem nebo jinou formou omezení nebo donucení, a měla by mít dostatečnou znalost a pochopení podstaty experimentu tak, aby jí bylo umožněno učinit informované a zasvěcené rozhodnutí. To vyžaduje, aby byl subjekt pokusu před udělením souhlasu obeznámen s povahou, dobou trvání a cílem pokusu; s metodou a zpo̊soby, kterými bude prováděn, se všemi komplikacemi a riziky, která se dají rozumně předpokládat a s účinky na jeho zdraví nebo osobnost, které mohou vzniknout z jeho účasti na pokusu. Povinnost a odpovědnost za zajištění kvality uděleného souhlasu leží na osobě, která pokus navrhla, řídí nebo se na něm podílí. Je to osobní povinnost, kterou nelze beztrestně přenést na jinou osobu.

2. Pokusy by měly být takové povahy, aby nesly plodné výsledky pro dobro společnosti, kterých by nebylo možné dosáhnout jiným způsobem, a neměly by být svou povahou náhodné nebo zbytečné.

3. Pokus by měl být založen a podložen výsledky předchozích testů na zvířatech a znalostech předchozí historie nemoci nebo jiného zkoumaného problému tak, aby očekávané výsledky ospravedlňovaly provedení pokusu.

4. Pokus by měl být prováděn tak, aby se zabránilo veškerému zbytečnému mentálnímu a fyzickému utrpení a zraněním.

5. Žádný experiment by neměl být prováděn $v$ těch př́ípadech, kde existuje důvod domnívat se, že může nastat smrt nebo zmrzačení, možná s výjimkou těch pokusů, kterých se jako subjekt účastní osoba experiment provádějící.

6. Míra podstupovaného rizika by nikdy neměla překročit míru společenské důležitosti problému, který má být pokusem vyřešen.

7. Měly by být provedeny řádné prŕípravy a zajištěna řádná zařízení ve snaze uchránit pokusný subjekt před byt' i nepravděpodobným nebezpečím zranění, zmrzačení nebo smrti.

8. Pokus by měl být prováděn pouze vědecky kvalifikovanými osobami. Nejvyšší stupeň schopností a péče by měl být požadován během všech fází pokusů po všech osobách, které pokus provádí nebo se ho účastní.

9. Během průběhu pokusu by měl být lidský subjekt oprávněn experiment ukončit, pokud dosáhl fyzického nebo mentálního stavu, ve kterém se mu pokračovaní pokusu zdá jako nemožné.

16 Rozsudek ve věci USA vs. Karl Brandt et al. z 19. srpna 1947. [online]. Dostupné na: http://www.loc.gov /rr/frd/Military_Law/pdf/NT_war-criminals_Vol-II.pdf. [cit. 23. 02. 2019].

17 Tamtéž. 
10. Během průběhu pokusu musí být vědec, který ho má na starost, připraven pokus ukončit během jakékoliv jeho fáze, pokud má důvod v dobré víře a na základě své odbornosti a pozorného úsudku, které se po něm požadují, věřit, že pokračování pokusu povede ke zranění, zmrzačení nebo smrti pokusného subjektu.“18

Tento soubor deseti pravidel později nazvaný Norimberský kodex významně ovlivnil vývoj medicínské etiky na celosvětové úrovni v druhé polovině dvacátého století, a právě proto je mu věnována další kapitola.

\section{Norimberský kodex}

Výše uvedený soubor etických pravidel dnes známý jako Norimberský kodex byl bezesporu jedním z nejvýznamnějších výsledků procesu s nacistickými lékaři. Je zřejmé, že byl formulován v reakci na průběh procesu, a že na jeho formulaci spolupracovali se soudci američtí lékařští experti, kteří během procesu působili jako svědci a znalci obžaloby. Určit konkrétního autora však není jednoduché i s přihlédnutím k tomu, že v pozdějších letech se nezávisle na sobě k výlučnému autorství kodexu přihlásili dva z významných amerických lékařských expertů, psychiatr a neurolog Leo Alexander a fyziolog Andrew C. Ivy, a zároveň vrchní prokurátor Telford Taylor šířil své přesvědčení, že autorem kodexu byl jeden z amerických soudců, Harold Sebring. ${ }^{19}$ Dá se předpokládat, že na výsledné podobě etického desatera se nějakým způsobem podíleli všichni výše uvedení a pravděpodobně i další osoby z týmu amerických lékařských expertů. Bez ohledu na otázku autorství je zřejmé, že autoři v kodexu zohlednili některé starší práce dotýkající se medicínské etiky (někteří autoři zmiňují jako zdroj inspirace díla Thomase Percivala, Williama Beaumonta či Clauda Bernarda) i základní materiál týkající se medicínské etiky - Hippokratovu př́ísahu. ${ }^{20}$

Nelze pominout ani skutečnost, že i na území Německa existovaly dokumenty, které upravovaly medicínskou etiku, at’ už šlo o tzv. Berlínský kodex, tedy nařízení vydané pruským ministerstvem pro náboženské, školské a medicínské otázky, které upravovalo některé otázky spojené s pokusy na lidských subjektech, či o tzv. Říšské pokyny pro oblast pokusů vydané v roce 1931 Říšským ministerstvem vnitra, které obsahovaly řadu regulací v oblasti pokusů na lidských subjektech. ${ }^{21} \mathrm{Na}$ obsah těchto ř́ŕšských pokynů často odkazují kritici Norimberského kodexu, kteří poukazují, že bez ohledu na to, že principy zakotvené ve výše uvedených rríšských pokynech nebyly nacistickým Německem vůbec dodržovány, jde o obecně dokonalejší, promyšlenější a podrobnější úpravu regulace pokusů na lidských subjektech než právě Norimberský kodex, nehledě na to, že některé body Kodexu vyvolávají dojem, že byly přímo z rríšských pokynů opsány. ${ }^{22}$

18 Tamtéž.

19 SHUSTER, E. Fifty Years later: The Significance of the Nuremberg Code. The New England Journal of Medicine, 1997, roč. 337, č. 20, s. 1436-1437. Dostupné také na: https://www.gvsu.edu/cms4/asset /F51281F0-00AF-E25A-5BF632E8D4A243C7/nuremberg_50_years_later.nejm.pdf.

20 ANNAS, G. J. - GRODIN, M. A. (eds.). The Nazi Doctors and the Nuremberg Code: Human Rights in Human Experimentation. Oxford: Oxford University Press, 1995, s. 122-126.

21 ANNAS - GRODIN (eds.)., op. cit., s. 127-131.

22 GHOOI, R. B. The Nuremberg Code - A critique. Perspectives in Clinical Research, 2011, roč. 2, č. 2, s. 73-75. Dostupné také na: http://www.picronline.org/temp/PerspectClinRes2272-4557991_123939.pdf. 
I přes výše uvedené je nutné konstatovat, že význam Kodexu nezpochybnitelně předčil význam Říšských pokynů, které byly de facto kompromitovány činy nacistického režimu v oblasti medicínského výzkumu a po skončení II. světové války zcela ztratily jakoukoliv relevanci i přes to, že byly formálně dokonalejší než Norimberský kodex. Zároveň je však nutné podotknout, že ani Norimberský kodex nenaplnil očekávání svých autorů. Kodex sice byl reflektován většinou národů a stal se inspirací pro různé národní úpravy, avšak nikdy nebyl inkorporován do vnitrostátního práva žádného státu a ani jeho vliv na kodifikace mezinárodního práva nebyl nijak značný. ${ }^{23}$ Dokonce ani ve Spojených státech nebyl Kodex využíván, a to ani podpůrně v soudních sporech, jejichž předmětem byla medicínská etika. Většina autorů se shoduje na tom, že tento osud potkal Kodex kvůli okolnostem jeho vzniku. Vzhledem k tomu, že Kodex vznikl v reakci na zvrácené nacistické zločiny, získal především v západním světě pověst „zákoníku pro barbary“, který zakotvuje zásady, které jsou civilizovaným lidem zcela zřejmé a přirozené, a které není nutné akcentovat tím, že by byly recipovány do vnitrostátního právního řádu. ${ }^{24}$

I přes výše uvedené je nutné konstatovat, že Norimberský kodex má v dějinách medicínské etiky své nezpochybnitelné místo už jen díky tomu, že byl inspirací a vzorem pro pozdější úpravy této problematiky. Na Norimberský kodex posléze navázala Helsinská deklarace Světové lékařské asociace z roku 1964, která některé principy z Kodexu převzala a některé naopak upravila nebo předělala a obecně se nesla v duchu zmírnění některých kategorických př́ikazů a zákazů obsažených v Kodexu. ${ }^{25}$ Helsinská deklarace, ačkoliv rovněž nebyla mezinárodně právně závazným dokumentem, se stala ještě výraznějším inspiračním zdrojem pro národní a regionální právní úpravu, přičemž sama hojně čerpala právě z Kodexu a zároveň vhodně doplnila další základní principy etického lékařského výzkumu. ${ }^{26} \mathrm{O}$ významu Helsinské deklarace svědčí i to, že je pravidelně novelizována a doplňována a reaguje tak na etické otázky, které vyvstávají s rozvojem lékařské vědy. Do dnešního dne byla Helsinská deklarace novelizována celkem devětkrát, naposledy v ř́́jnu 2013.27

$\mathrm{V}$ návaznosti na to, co bylo řečeno $\mathrm{v}$ předchozím textu, se nabízí otázka, zda lze vliv Norimberského kodexu pozorovat v právním řádu České republiky a v názorech českých odborníků zabývajících se lékařskou etikou. Krátká odpověd’ zní: Ano, tento vliv je rozhodně možné pozorovat. Při pohledu na mezinárodní smlouvy, kterými je Česká republika vázána, nalezneme v článcích 15-18 Úmluvy na ochranu lidských práv a důstojnosti lidské bytosti v souvislosti s aplikací biologie a medicíny (dále Úmluva o lidských právech a biomedicíně) formulace, které až nápadně připomínají formulace z Norimberského kodexu,

23 MAZUR, G. Informed Consent, Proxy Consent, and Catholic Bioethics: For the Good of the Subject. Dordrecht: Springer Science \& Business Media, 2011, s. 19-20.

24 MAZUR, op. cit., s. 20.

25 FADEN, R. R. - BEAUCHAMP, T. L. A History and Theory of Informed Consent. Oxford: Oxford University Press, 1986, s. 156-157.

26 BRONFMAN, L. - SHRIVER, C. D. - GUTCHELL, E. The Clinical Perspective. In: HU, H. - MURAL, R. J. - LIEBMAN, M. N. (eds.). Biomedical Informatics in Translational Research. Norwood: Artech House, 2008, s. 12.

27 Helsinská deklarace Světové lékařské asociace - Etické zásady pro lékařský výzkum s účastí lidských bytostí z června 1964, ve znění z řijna 2013. [online]. Dostupné na: https://www.wma.net/policies-post/ wma-declaration-of-helsinki-ethical-principles-for-medical-research-involving-human-subjects/. [cit. 03. 10. 2020]. 
přičemž ve vztahu ke Kodexu je klíčový zejména článek 16 - první odstavec článku 16 odpovídá 2 . bodu Kodexu, druhý odstavec pak 6. bodu, čtvrtý a pátý odstavec pak korespondují s 1. a 9. bodem Kodexu, avšak míra ochrany člověka obsažená v Úmluvě je vyšší. ${ }^{28}$ Jediný odstavec článku 16, který nemá svou obdobu v Kodexu, je ten třetí, dle kterého „musí být výzkumný projekt schválen příslušným orgánem po nezávislém posouzení jeho vědeckého přínosu včetně zhodnocení významu cíle výzkumu a multidisciplinárního posouzení jeho etické přijatelnosti““ ${ }^{29}$ Nezávislé posouzení vědeckého prínosu a etické prrijatelnosti se jeví jako značný krok dopředu, který ještě více posiluje původní garance obsažené v Kodexu. V rámci práva Evropské unie lze poukázat na článek 3 Listiny základních práv Evropské unie, jehož druhý odstavec zavádí, obdobně jako Kodex, povinnost získat svobodný a informovaný souhlas dotčené osoby zákonem stanoveným způsobem a zároveň ve svém třetím odstavci zakazuje eugenické praktiky, což lze jednoznačně vnímat jako reakci na nacistické medicínské zločiny. ${ }^{30}$ Dá se říci, že principy obsažené v Norimberském kodexu se objevují i v dnes účinném trestním zákoníku. V př́ípadě, že vztáhneme § 31 zabývající se prŕípustným rizikem jako okolností vylučující protiprávnost na otázku lékařského experimentu, vidíme, že zejména jeho druhý odstavec v zásadě parafrázuje Norimberský kodex když, aby šlo o př́pustné riziko, vyžaduje v prŕípadě činnosti ohrožující život nebo zdraví člověka souhlas daného člověka, přičemž zamýšlený výsledek musí odpovídat míře rizika a zároveň nesmí odporovat požadavkům jiného právního předpisu, zásadám lidskosti a dobrým mravům. ${ }^{31}$ Je tedy patrné, že i přes stáří Kodexu a skutečnost, že nikdy nebyl prrímo inkorporován do žádného systému vnitrostátního práva, jsou principy v něm obsažené reflektovány i v dnes platných předpisech.

Zásady obsažené v Kodexu jsou i dnes analyzovány a interpretovány v dílech odborníků, zabývajících se lékařskou etikou. Miloš Maurer a Helena Haškovcová hovoří o střetu autonomie pacienta s paternalistickým př́stupem $\mathrm{s}$ tím, že v posledních desetiletích je zřetelný posun od paternalistické koncepce ke koncepci partnerské, dle kterých má lékař brát osobu ve své péči jako rovnocenného partnera. ${ }^{32}$ Tento trend lze pozorovat i ve vývoji, který vedl k vytvoření Norimberského kodexu. Nacistické lékařské pokusy představovaly strašlivou perverzi paternalistického prŕístupu, kdy lékaři, kteři strašlivé pokusy prováděli, nevnímali své oběti jako živé, rovnocenné lidské bytosti, zcela ignorovali jejich zájmy a bez dalšího poškozovali jejich zdraví a ničili jejich životy. Norimberský kodex pak představuje razantní př́íklon k partnerské koncepci, kdy lékař dostává jednoznačná omezení a pacient je prostřednictvím informovaného souhlasu více partnerem než objektem. K zajímavému závěru pak dochází Marta Munzarová, dle které různé kodexy a deklarace

28 Sdělení Ministerstva zahraničních věcí o přijetí Úmluvy na ochranu lidských práv a důstojnosti lidské bytosti v souvislosti s aplikací biologie a medicíny: Úmluva o lidských právech a biomedicíně č. 96/2001 Sb. m. s. In: Sbirka mezinárodních smluv. Č. 96/2001, částka 44, s. 1906-1907. Dostupné také na: http:// ftp.aspi.cz/opispdf/2001/044m2001.pdf.

29 Tamtéž.

30 Článek 3 Listiny základnich práv Evropské unie z 26. řijna 2012 (201/C 326/02). [online]. Dostupné na: https://eur-lex.europa.eu/legal-content/CS/TXT/PDF/?uri=CELEX:12012P/TXT\&from=CS. [cit. 03. 10. 2020].

$31 \S 31$ zákona č. 40/2009 Sb., trestní zákoník. In: Sbirka zákonů. Č. 40/2009, částka 11, s. 359. Dostupné také na: https://www.psp.cz/sqw/sbirka.sqw?cz=40\&r=2009.

32 VÁCHA, M. - KÖNIGOVÁ, R. - MAUER, M. Základy moderní lékařské etiky. Praha: Portál, 2012, s. 99-102. 
nemohou zcela osobu účastnící se experimentu ochránit a ve výsledku rozhoduje především etická integrita osoby, která pokus provádí, a proto je nutné, aby tuto integritu u sebe rozvíjel každý lékař provádějící nějaké medicínské experimenty. ${ }^{33}$

\section{Závěr}

Proces USA vs. Karl Brandt et al. nebyl jediným z poválečných procesů, ve kterém byly souzeny zločiny nacistických lékařů, zdravotnického aparátu a představitelů nacistické státní správy, kteří tyto zločiny umožnili (z jiných procesů lze např́klad zmínit proces s polním maršálem Erhardem Milchem, který se uskutečnil v rámci „Následných norimberských procesư“, proces s personálem Hadamarského zdravotnického zařízení, či procesy s personálem jednotlivých koncentračních táborů, které se uskutečňovaly ve všech okupačních zónách Německa a na území osvobozených států), avšak patrně šlo o nejvýznamnější proces z hlediska symboliky. V samotném procesu bylo prokázání viny jednotlivých obžalovaných pouze jedním z cílů americké vojenské prokuratury, stejně podstatným cílem byla i symbolická obžaloba amorálního myšlenkového směru, jakým nacismus beze sporu byl, který dokázal eliminovat základní a do té doby nezpochybnitelné etické zásady lékařství, tedy povolání, jehož je profesní etika zvláště důležitou a esenciální součástí, a který pomocí výkonného státního aparátu legalizoval pokusy, které se již na prvý pohled jeví jako šílené, bestiální a zvlášt' zavrženíhodné. Skutečnosti, které byly během procesu prokázány, by měly sloužit jako varovně zdvižený prst, který by i v dnešní době měl upozorňovat na to, jak snadno a rychle mohou odpadnout morální zásady a principy, které se zdají být přirozené, a které by snad ani nikoho nenapadlo zpochybňovat, ve chvíli, kdy se nehodí vládnoucí moci.

Samotný Norimberský kodex upravující základní etická pravidla při medicínském procesu se sice nikdy nestal zásadním legálním dokumentem, avšak v symbolické rovině svým obsahem i pohnutými událostmi, které vedly k jeho vzniku, udal směr vývoje lékařské etiky v druhé polovině dvacátého století. Jak však ukazuje osud Říšských pokynů pro oblast pokusů, pouhá deklarace etických principů nemůže obstát, pokud si tyto principy neosvojí jejich adresáti a nepřijmou je za své. Na rozdíl od nich však Norimberský kodex stále rezonuje jak v platné legislativě, tak v doktrinálních názorech, a principy v něm obsažené jsou stále platné a v různých obměnách tvoří jeden ze základů lékařské etiky v oblasti lékařských experimentů. $V$ dnešní době je lékařská etika obecně běžně vyučována na lékařských fakultách vysokých škol a díky tomu dochází k pevnému zakotvení základních etických zásad profese v myšlení budoucích lékařů a posílení jejich etické integrity, což je zcela jistě př́klad hodný následování i pro jiné obory, ve kterých hraje profesní etika významnou roli.

33 MUNZAROVÁ, M. Lékařská etika v kontextu klinického výzkumu. Klinická farmakologie a farmacie, 2007, roč. 21, č. 3-4, s. 127. 